\title{
Simas Eric Learning Model (SELM): Enhance Student' Metacognitive Skill Based on the Academic Level
}

\section{Ericka Darmawan}

Universitas Tidar, Indonesia, darmawan.ericka@untidar.ac.id

\section{Siti Zubaidah}

Universitas Negeri Malang, Indonesia, siti.zubaidah.fmipa@um.ac.id

\section{Rizhal Hendi Ristanto}

Universitas Negeri Jakarta, Indonesia, rizhalhendi@unj.ac.id

\section{Muhammad Rizal Akbar Zamzami}

Universitas Islam Raden Rahmat, Malang, Indonesia,m.rizalzami@gmail.com

\section{Bevo Wahono}

Universitas Jember, Indonesia, \& National Taiwan Normal University, Taiwan, bevo.fkip@unej.ac.id

Metacognitive skills play a central role in the student learning process. However, there is a limited report consider regarding any learning model that can enhance students' metacognitive skills, particularly related to students' academic level. This current research aimed to perform the Simas Eric Learning Model (SELM) by considering students' academic level, namely, high and low academic levels toward metacognitive skills. The SELM is one of the learning model based on constructivism focusing on student-centered activities. The total of the participants was 254 senior high school students. The categorization of the sample was based on the homogeneity test in their IQ score. IQ tests had been conducted by schools before doing research in collaboration with higher education institutions that have official certificates measuring IQ. Test on the metacognitive skills was done before and after the learning and was analyzed by using Analysis of Covariance and Least Significance Different tests. The research results show that SELM was able to improve students' metacognitive skills significantly. The metacognitive skills of students who were taught by SELM were $71.9 \%$ higher than those who were taught by the conventional learning model. SELM can be used to improve students' metacognitive skills in learning biology.

Keywords: academic level, biology, learning model, metacognitive, SELM

Citation: Darmawan, E., Zubaidah, S., Ristanto, R. H., Zamzami, M. R. A., \& Wahono, B. (2020). Simas Eric Learning Model (SELM): Enhance Student' Metacognitive Skill Based on the Academic Level. International Journal of Instruction, 13(4), 623-642. https://doi.org/10.29333/iji.2020.13439a 


\section{INTRODUCTION}

Metacognitive research in a teaching and learning process has become a central part and issue in education recently (Pratama, 2018; Lestari, Ristanto \& Miarsyah, 2019a). Metacognitive skills have become an essential part of 21st-century education (Zohar, A., \& Barzilai, 2013; Miharja, Hindun \& Fauzi; 2019). Applying of metacognitive learning activities will be meaningful and be able to involve students' activeness in learning knowledge; moreover it can build autonomous learners who are able to ask questions well, search for answers to questions raised and find answers independently (Nielsen, 2019; Darmawan et al., 2018).

Metacognitive skills refer to the activities of controlling, monitoring, and doing selfregulation that occurs when learning and solving a problem, as stated by Bannert \& Mangelcamp (2008). Metacognitive skill concerns procedural knowledge related to actual regulations, and control over a person's cognitive processes and learning activities (Asy' ari \& Ikhsan, 2019). Students with metacognitive skills will be able to understand their academic strengths and weakness. Then, from their background knowledge, students can adjust the need to fulfill the demands of specific tasks (Lestari, Ristanto \& Miarsyah, 2019b; Permana \& Chamisijatin, 2019). Based on their knowledge and skills, students may regulate their involvement on tasks in an effort to optimize the process and learning outcomes. For instance, when the students are facing any obstacle to their work, they will re-think and revise based on the target goal of the task.

The empowerment of metacognitive skills through the learning process is needed. Consequently, students can be independent (Martin, 2010; Susantini, Indana, Isnawati, \& Nursanti, 2019). Darmawan et al., (2018) explained that metacognitive skills relate to the procedural knowledge that adheres to the actual regulation of, and control over one's cognitive processes and learning. It is also called as executive skills. It includes analyzing the task, planning, monitoring, checking or evaluating, recapitulating, and reflecting that are manifested in students while doing the project. Furthermore, the implementation of learning that enforces metacognitive skills is influenced by learning strategies with focused on reading activity (Rican, 2015; Hariyadi \& Corebima, 2019; Sheikh, Soomro, \& Hussain, 2019).

Another essential factor that should be given more attention in teaching and learning process is students' academic level since it will give an impact on the ability of students in learning activities. The academic level of each student is a factor that can influence the process and the learning outcome. The definition of a student's academic level is the degree of actual competence to perform in scholastic or educational activities (Darmawan, 2016). Furthermore, academic learning achievement level is measured in relation to what is attained at the end of a course, since it is the accomplishment of longterm, medium or short-term objective of education (Alves, Gomes, Martins, \& Almeida, 2017; Borovay, Shore, Caccese, Yang, \& Hua, 2019). Therefore, it can be said that the students' academic level is a potency of the student to achieve high academic standards. The academic level can be represented by IQ test scores (Braaten \& Norman, 2006), which is done for the first time, entering a higher level of education. IQ scores reflect the capability of students in answering the questions, which have already standardized (valid and reliable). Based on the differences in academic level, this current research is 
expected to know the achievement of student's metacognitive skills whose higher and lower academic level.

One of the learning models that potentially can improve metacognitive skills is the constructivism learning model, which empowers and improves students' learning outcomes. The Simas eric learning model (SELM) is based on a constructivisminnovative learning model that applies student-centered through an exciting Biology learning. The SELM was developed by Darmawan (2012) and revised by Darmawan, Zubaidah, Susilo, and Suwono (2016) using LDC (Learning Development Cycle) like in figure 1, based on Siemens (2005) with the addition of communication syntax for students both in cooperative groups and in classical. It considers four domains: transmission, acquisition, emergence, and accretion.

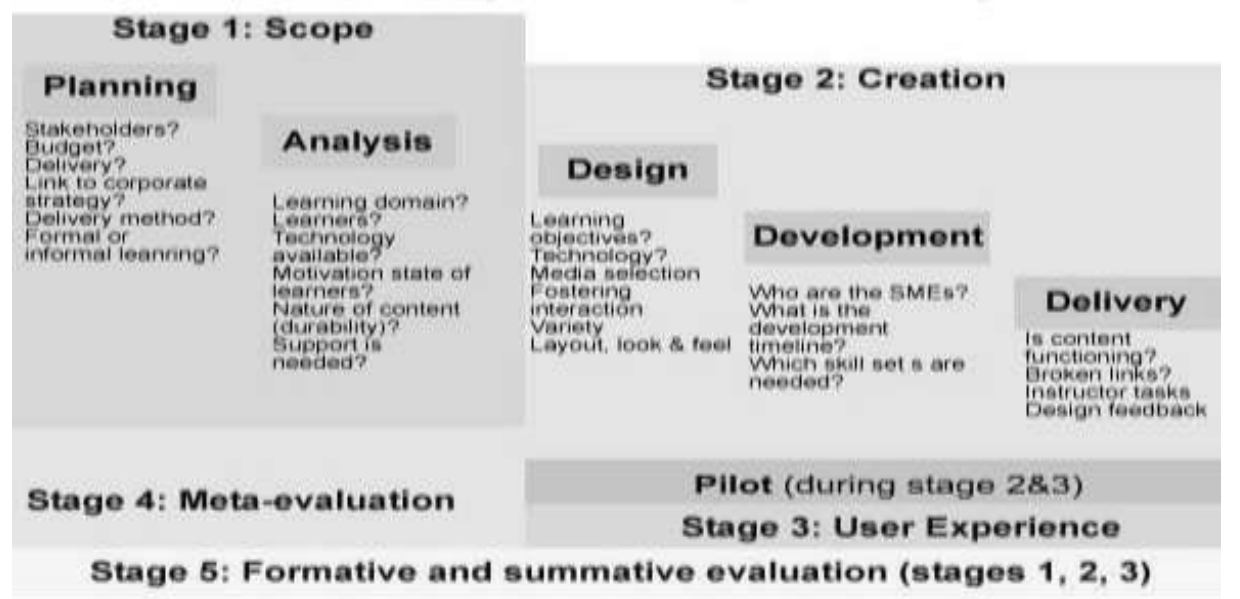

Figure 1

The 5 (five) Steps in LDC (Siemens, 2005)

A feasibility test of SELM was very reasonable. The research conducted by Darmawan, et al., (2018) using SELM at an Indonesian secondary school, showed the influence of SELM on the metacognitive skills of a Biology class' students.

The pattern of Biology learning activities in Indonesia tends to cognitive learningoriented and yet seeks the empowerment of students' metacognitive skills. Biology as a part of science requires teachers to prepare the future generations that are fit and adaptive to respond to all demands as well as will help students in the process of thinking, formulating a question, and finding an answer (Fuad et al., 2017; Supriyatin, Rahayu, Ristanto \& Ichsan, 2019). However, public and private high school students had not been taught by learning strategies that was able to empower metacognitive skills (Siswati, 2017; Buku et al., 2016; Sele, 2016). Kristiani et al. (2015) also reinforces the importance of the application of learning that can enhance metacognitive skills for high school students. The low metacognitive skills of students in Indonesia were also examined by Lukitasari (2014) and Runisah (2017), who stated that students' metacognitive skills in Indonesia were still low because a few teachers that knowing the importance of metacognition and apply it in teaching and learning activities. Moreover, 
Sungur and Yerdelen (2011) revealed that the low of metacognitive skill was also found on most of the Turkish high school biology students. Those facts are strong evidence that we need an innovative strategy concerning enhancing the metacognitive skill of students throughout the world.

Furthermore, research conducted by Sumiati, Mahanal \& Sunarmi (2016) on learning outcomes and retention of secondary school students showed that students taught by SELM had significantly different learning outcomes both control and experimental class, the average difference corrected by $33.56 \%$. The result of students' retention in the control class was significantly different from the experimental class, with an average adjusted mean of $33.42 \%$. They have shown that SELM was able to affect students' learning outcomes and retention. However, in the previous study, SELM was still applied on a limited scale (only in one school). Then, a study is necessary to conduct on a large scale by an adequate population and sample that is expected to provide better research data to be generalized.

Therefore, this current study was conducted by using a large sample to determine the effect of the SELM on Biology subject to students' metacognitive skills based on the academic level. The main goal of this study is to assess the impact of SELM of the students' metacognitive skills, the role of the academic level of the metacognitive skills, and the interaction of SELM and academic level toward the metacognitive skills of high school students. Hence, a comprehensive result concerning the students' metacognitive skills by using SELM, particularly on Biology subject, was expected to gain in this current research.

\section{LITERATURE REVIEW}

\section{The Importance of Metacognitive Skills}

Moore \& Dwyer (2001) state that metacognitive is consciousness of the thinking process about what is known and what will be done. Choi (2005) explained that metacognitive is knowledge about mental processes and controls the process to achieve the purpose. Therefore, metacognitive has been used to regulate and control the thinking process conducted by students in terms of solving a problem through verification. Hence, the goal of solving a problem can be achieved effectively and efficiently.

Regarding the purpose of metacognitive skill is to regulate and thinking process, Hogan et al. (2015) define metacognition as "thinking about thinking." Hogan et al. (2015) also distinguished between the two components of metacognition, namely: knowledge of cognitive processes and products to control, monitor, and evaluate the cognitive processes. Understanding of cognition depends on these components of metacognitive knowledge about themselves, tasks and strategies, knowledge on how to use strategies, and metacognitive experiences. According to Pratama (2018), metacognitive knowledge is essential in a variety of cognitive activities. It is activated intentionally when the nature of the learning task requires conscious thought and accuracy, when getting a new task, or when learning is not correct or complete (Miyamoto, Pfost, \& Artelt, 2019).

Schraw, Flowerday \& Lehman (2001) distinguished between metacognitive knowledge and metacognitive skills. Metacognitive knowledge refers to the declarative knowledge of individuals in learning, strategies, and tasks. Metacognitive skills can be defined as 
the conscious control held by individuals on their cognitive processes (Lauca, 2003). Metacognitive skills are used in control activities, monitoring, and self-regulation when learning and solving a problem, according to a statement from Caro et al. (2019) and Bannertet al., (2008). Metacognitive skills regarding procedural knowledge relate to regulation and controlling over the process of a person's cognitive and learning activities (Caro et al., 2019; Pratama, 2018). Elaboration of activities used in the appropriate learning activity can grow metacognitive skills such as drawing conclusions, recapitulation, and submitting an explanation (Darmawan et al., 2005).

\section{The Role of Students' Academic Level in Education}

According to Suskie (2018) academic level is a description of the knowledge and skill levels of students toward a topic that been learned. This fundamental knowledge is used by students to construct new extensive and sophisticated understanding. Basically, in terms of academic level and intelligence, students can be classified into three levels, they are: 1) students whose below-average academic level or lower academic level, 2) students whose average academic level, and 3) students whose above-average academic level. The students whose academic levels will produce different learning outcomes when they are taught by similar learning model (Borovay, et al., 2019; O'Connor, Cloney, Kvalsvig, \& Goldfeld, 2019). The academic level needs to be empowered, especially to the lower academic level, to get the same result with those whose different levels (White, 2006). Based on the differences in academic level, this current research is expected to know the achievement of student's metacognitive skills whose higher and lower academic level.

Amin \& Sukestiyarso (2015); Alves, et al (2017); Dent (2016) stated that students with higher academic levels have a better-thinking achievement than students with lower academic skills. In line with Lam and Zhou (2019); Sele (2016) found that students with a higher academic level possess a higher level of thinking than students with lower academic levels. Moreover, Gagne (1995) said that knowledge affects the development of student thinking skills. This is due to students with high academic level have the knowledge that can be used to solve complex problems involving higher cognitive. Thus, students' academic levels will affect their metacognitive skills (Yusnaeni, 2018; Darmawan, 2016; Loes, 2017).

Darmawan et al., (2018) argued that students who are below the average have a learning ability below the speed of learning students in general, while students who are above average has a higher ability of learning than the speed of education of other students. If students who have different academic levels are given the same learning experience, the learning outcomes will vary according to the grade of the academic level.

Darmawan et al. (2016) showed an important thing related to students' academic level. They are: 1) consistently demonstrated a link between academic skills to learning outcomes, and 2) the quality of the teaching material may affect academic level, and it will affect learning achievement. Darmawan et al. (2018) stated that students would be able to learn well if they have mastered all the prerequisites in the form of knowledge, skills, and attitudes. Therefore, students will use prior knowledge to interpret information and experiences. 


\section{Simas Eric Learning Model (SELM)}

The SELM was developed based on constructivist and cognitivism theory (Siemens, 2005; Darmawan, 2015). The constructivist learning theory is based on the principle that knowledge created from experience (Almala, 2005; Fauzi \& Fariantika, 2018). The empirical background of the emergence of the SELM learning model is in accordance with the opinion of Siemens (2005), that the natural environment and social environment has changed, media and technology have also changed so that learning models are needed to bridge the gap between students' academic knowledge needs, information and technology development.

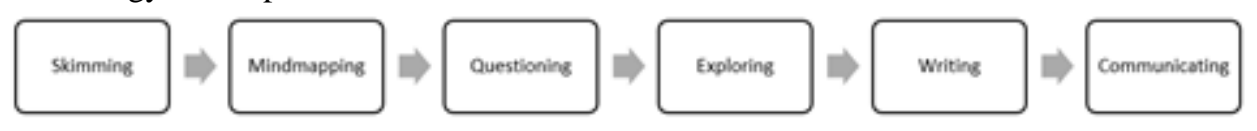

Figure 2

The syntax of SELM (Darmawan et al., 2016)

Activities of teachers and students like in figure 2 in this model are as follows: (1) skimming: the teacher gives orders to the students to read the material at home. Students study material focuses on the title, introduction, pictures, tables, graphs, summaries, and conclusions. (2) Mind mapping: the teacher facilitates students to create a mind map based on their skimming results. Students create their mind mapping and skimming in a piece of paper as their authentic work. (3) Questioning: The teacher divides students into heterogeneous groups and asks students to arrange a high-level question by why and how keywords. Students independently create questions and then discuss in groups to get the appropriate questions. (4) Exploring: the teacher gives students the chance to reread, if it is necessary, they may do experiment and discuss with friends in their group to find a solution. Students re-read the material thoroughly to get a solution to the question. (5) Writing: the teacher asks students to write down the answers in the sheet that has been prepared by the students. Students write answers by reviewing and discussing the solutions with the group. (6) Communicating: The teacher gives students a chance to presentation and discussion in the classical style.

SELM's research with the theme of increasing critical thinking skills in Biology subjects for high school students in Indonesia has been conducted by Darmawan (2016) with the results that students taught with SELM have critical thinking skills $65.3 \%$ higher than students taught with conventional learning model. Student learning motivation can also be improved by using SELM, as has been done by Herlina (2018). Putri et al., (2018) also reported that with SELM high school students in Pekan Baru-Indonesia City had $80.61 \%$ cognitive learning outcomes while in the conventional class was $72.44 \%$.

\section{METHOD}

\section{Research Design}

This study was quasi-experimental research with a pretest-posttest non-equivalent control group design. The independent variable in this study was a learning model (SELM and conventional learning approach based on teacher-centered), while the moderator variables, were the higher and lower academic level. The control variables in this study were the ability of teachers, the number of learning hours, and the learning 
material. The dependent variable was metacognitive skills. Learning activities carried out within 12 weeks' time periods, adjust to the duration of biology subject matter used as research subjects

\section{Participant}

The participants of the study were a high and low academic level of eleventh graders of science class of a senior high school in Malang, Indonesia. The total of the participants was 254 students. The homogeneity test randomly chose the samples in their IQ scores. The participant had been taken from 4 high schools in Malang city, East Java, Indonesia. The samples of this research were the students of class XI Science Class-6 of state senior high school 1 Malang consisting of 33 participants. The participants of class XI Science Class-6 senior high school 3 Malang is composed of 30 participants. The participants of class XI Science Class-1 senior high school 6 Malang is consisting of 34 participants and the participants of class XI Science Class-2 of senior high school 7 Malang composed of 32 participants. The research population was all students of class XI Public High School in Malang City 2014/2015 academic year. The number of Public Senior High School in Malang City at the time of the study was 10 Schools.

\section{Procedure}

There were several steps employed in this study. The first step was metacognitive skills rubric integrated with essay tests that were used to determine the score of students' metacognitive skills, as in table 1. Every class was divided into a high and low academic level. The IQ test was conducted to determine the academic test score of students, IQ tests had been conducted before research by schools in collaboration with higher education institutions that have official certificates measuring IQ. The high and low academic scores determined to sort all samples based on IQ scores (Braaten \& Norman, 2006). High academic abilities are students with the most top IQ test scores based on the IQ test sequence; then, it takes $20 \%$ of the upper group. While lower academic abilities are students with the lowest IQ test scores in each class, then $20 \%$ of the low group, which is then used as research subjects.

Table 1

Examples of Questions and Metacognition Rubrics

\begin{tabular}{|c|c|c|c|}
\hline \multicolumn{2}{|c|}{ No Question } & Score & Metacognitive Indicator \\
\hline \multirow[t]{5}{*}{1} & \multirow{5}{*}{$\begin{array}{l}\text { There are } 3 \\
\text { types of } \\
\text { drinks } \\
\text { (isotonic, } \\
\text { hypertonic } \\
\text { and } \\
\text { hypotonic) } \\
\text { provided to } \\
\text { athletes } \\
\text { during a } \\
\text { running race. } \\
\text { What type of } \\
\text { drink do you } \\
\text { recommend } \\
\text { for athletes? }\end{array}$} & 0 & No answer \\
\hline & & 1 & $\begin{array}{l}\text { The answers are not written in their own sentences. The sentence sequence of } \\
\text { answers is less/ not harmonious and less/ not systematic. The answer is lack/ } \\
\text { not logic, in grammar is not correct, not supported by explaining the reasons } \\
\text { (analytic, evaluative, or creative explanation), and the answer is not correct. }\end{array}$ \\
\hline & & 2 & $\begin{array}{l}\text { The answers are not written in their own sentences. The sentence sequence of } \\
\text { answers is less/ not harmonious and less/ not systematic. The answer is less/ } \\
\text { not logical, in grammar is not correct, is not supported by explaining the } \\
\text { reasons (analytic, evaluative, or creative explanation), and the answer is } \\
\text { incorrect }\end{array}$ \\
\hline & & 3 & $\begin{array}{l}\text { The answers are not written in their own sentences. The sentence sequence of } \\
\text { answers is less/ not harmonious and less/ not systematic. The answer is less/ } \\
\text { not logical, in grammar is not correct, supported by explaining the reasons } \\
\text { (analytic, evaluative, or creative explanation), and the answer is correct }\end{array}$ \\
\hline & & 4 & The answers are not written in their own sentences. The sequence of sentences \\
\hline
\end{tabular}




\begin{tabular}{ll}
\hline $\begin{array}{l}\text { How } \\
\text { confident are } \\
\text { you with } \\
\text { your answer? } \\
\begin{array}{l}\text { Explain your } \\
\text { reason! }\end{array}\end{array}$ & $\begin{array}{l}\text { is a harmonious and systematic answer. The answer is logic in correct } \\
\text { grammar, supported by explaining reasons (analytic, evaluative, or creative } \\
\text { explanation), and the answer is correct }\end{array}$ \\
\cline { 2 - 3 } & $\begin{array}{l}\text { The answers are written in their own sentences. The order of answers is less/ } \\
\text { not harmonious and less/ not systematic. The answer is the lack of logic in } \\
\text { grammar is not correct, supported by explaining the reasons (analytic, } \\
\text { evaluative, or creative explanation), and the answer is correct. }\end{array}$ \\
\cline { 2 - 3 } & $\begin{array}{l}\text { The answers are written in their own sentences. The order of answers is } \\
\text { harmonious and systematic. The answer is that logic in grammar is incorrect, } \\
\text { supported by explaining reasons (analytic, evaluative, or creative explanation), } \\
\text { and the answer is correct. }\end{array}$ \\
\hline 7 & $\begin{array}{l}\text { The answers are written in their own sentences. Harmonious and systematic } \\
\text { answer sequence. The answer is logic in correct grammar, supported by } \\
\text { explaining reason (analytic, evaluative, or creative explanation), and the answer } \\
\text { is correct. }\end{array}$ \\
\hline
\end{tabular}

The study was conducted on Biology subjects for high school class XI students on cell material, tissue material in plants, and tissue material in animals. The Material selected for research was in accordance with the distribution of the biology curriculum at the time the study was conducted. The implementation of learning in class, students with low academic ability, and high academics were not separated during learning, but when analyzing data related to academic abilities, both of them were separated. The experimental class was taught with SELM, while the control class used conventional learning models.

\section{Data Analysis}

Data were analyzed using inferential statistics. Before the data were analyzed by using an Analysis of Covariance (ANCOVA), the data were tested by normality and homogeneity of variance first. One-Sample Kolmogorov-Smirnov was performed to test the normality of data, while the homogeneity data was tested by Levene's Test of Equality of Error Variances. The test was carried out with the statistical analysis program of Statistical Package for the Social Sciences (SPSS) 18.0 for Windows and statistical tests performed at the significance level of $5 \%$.

\section{FINDINGS}

Summary of test results about the influence of SELM and academic level of the students' metacognitive skills shown in Table 2. Based on the result showed that the F-count treatment difference among learning models (classes) is 73.405 , with the P-value 0,000. The value can be interpreted that there is an influence on the student's metacognitive skills in learning model application. F-count on a treatment difference of academic level was equal to 143.249 with a p-value of 0.000 . P-value $<\alpha(0.05)$, can be interpreted that there is no influence on the achievement levels of academic level students metacognitive skills. F-count on different treatment interaction of learning model application and academic level is equal to 1.802 with p-value 0.181 . It means there is no interaction between the learning model and academic level to the achievement of high school students' metacognitive skills. 
Table 2

The Result Analysis of Metacognitive Skills, Learning Model, and Academic Level

\begin{tabular}{llllll}
\hline Source & Type III Sum of Squares & Df & Mean Square & F & Sig. \\
\hline Corrected Model & $48771.678^{\mathrm{a}}$ & 4 & 12192.919 & 69.366 & .000 \\
Intercept & 24687.225 & 1 & 24687.225 & 140.446 & .000 \\
Pretest_Metacognitive & 10730.678 & 1 & 10730.678 & 61.047 & .000 \\
Class & 12902.888 & 1 & 12902.888 & 73.405 & .000 \\
Academic & 25179.875 & 1 & 25179.875 & 143.249 & .000 \\
Class * Academik & 316.708 & 1 & 316.708 & 1.802 & .181 \\
Error & 27245.422 & 155 & 175.777 & & \\
Total & 601802.000 & 160 & & & \\
Corrected Total & 76017.100 & 159 & & & \\
a. R Squared =.642 (Adjusted R Squared =.632) & & & & \\
\hline
\end{tabular}

\section{The influence of SELM toward metacognitive skills of high school students}

Based on an analyzed by Least of Significant Differences (LSD) test shows that the average pretest score was 24.78 , and the posttest score was 48.29 with the increasing of metacognitive skills, approximately $102.03 \%$. Besides, the class taught by SELM shows that the average score of the pretest was 24.07 , and the posttest score was 66.49 , with the increasing of metacognitive skills is $179.23 \%$. The difference percentage between conventional class and SELM class is $77.2 \%$.

\section{The influence of academic level toward metacognitive skills of high school students}

The LSD test results of the influence of differences in academic abilities on metacognitive skills are presented in Table 3. Based on the results of the LSD test, it can be seen that the achievement of high academic metacognitive skills of students is significantly higher than in the low academic level.

Table 3

LSD Test Results Effect of Differences in Academic Ability on Metacognitive Skills

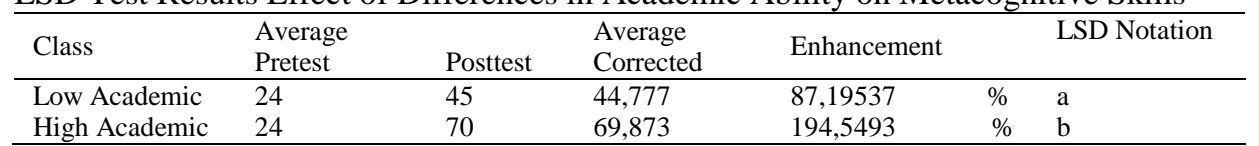

The interaction of SELM and academic level toward metacognitive skills of high school students

An interaction between SELM and students'academic level to increase the metacognitive skills of high school students is shown in Table 4. Although the results of Anacova testing showed there is no difference between the interactions, in fact, the result of LSD indicates that classes with low academic levels taught by SELM increase in metacognitive skills. It was not significantly different from high academic level students that were shown with conventional learning. 
Table 4

LSD Test Results on the Effect of Interaction Learning Model and Academic Level toward Metacognitive Skills

\begin{tabular}{|c|c|c|c|c|c|}
\hline \multirow[t]{2}{*}{ Treatment interaction } & Mean & & Mean & \multirow{2}{*}{ Enhancement } & \multirow{2}{*}{$\begin{array}{l}\text { LSD } \\
\text { notation }\end{array}$} \\
\hline & Pretest & Posttest & Corrected & & \\
\hline Conventional-Low & 25.44 & 38.33 & 37.21 & $52.28 \%$ & $\mathrm{a}$ \\
\hline SELM-Low & 23.83 & 52.24 & 52.34 & $125.58 \%$ & $\mathrm{~b}$ \\
\hline Conventional-High & 23.11 & 58.24 & 59.47 & $157.11 \%$ & $\mathrm{~b}$ \\
\hline SELM-High & 25.92 & 81.75 & 80.26 & $229.11 \%$ & \\
\hline
\end{tabular}

Based on Table 4, it can be shown that the highest achievement of metacognitive skills was the class of high academic level students taught by using SELM. In contrast, the lowest performance of metacognitive skills was demonstrated by the class of low academic level students by using the conventional learning model. Another exciting thing in this study is that there are differences in metacognitive skill achievement between the high academic level of students taught by the conventional learning model and the low academic level of students taught by SELM.

\section{DISCUSSION}

\section{The Influence of SELM on students' Metacognitive Skills}

The SELM significantly empowers the metacognitive skills of students, the cause of difference percentage on students' metacognitive skills in detail is described as follows. The first stage of SELM is skimming as an independent effort of students to examine a matter quickly by taking the subject matter of the material. Reading is a metacognitive skill because the skimming process will bring procedural knowledge (Caro et al., 2019). This skill refers to the knowledge of doing something, in the context of this study, students think about what they have learned from cell material, tissue material in plants, and tissue animals concepts. Most of this knowledge is represented as heuristics to know how to get the material presented in the book and take the main ideas of the material. The opinion of Cubukcu (2008) and Alexander \& Jetton (2000), they used any strategies to develop metacognitive skills that will encourage students to build a new vocabulary and improve reading comprehension skills.

The second stage is mind mapping. This stage encouraged students to depict out any plans to use one of the students' cognitive skills, such as activating prior knowledge and organizing the material to be read. Students will also examine their understanding of the material or set another goal; the process monitoring indicates the need for regulatory processes (Darmawan et al., 2019). Handoko (2016) stated that by reading a particular topic, students learn from written references from various learning resources both offline and online, thus converting the knowledge contained in references into tacit knowledge in their brain. That activity is a metacognitive activity referring to the monitoring of students' understanding when it would create a mind map. Mind mapping is created in a4 size paper blank. Mindmap is provided in the student worksheet then students create a mindmap with various forms of creativity and color. Skimming and mind mapping show that metacognitive skills including knowledge of cognition and regulation of cognition. When students use declarative, procedural knowledge, conditional planning, monitoring, and evaluation in creating a mind map, students consciously involve in the 
using of metacognitive skills. Several kinds of research have used mind maps to help adult learners become more patient as they create mind map and products based on their knowledge and understand the learning process (Jones, Ruff, Syder, Petrich \& Konce, 2002; Liu, Zhao, Ma \& Bo, 2014; Riswanto, 2012).

Questioning, exploring, writing, and communicating are the next stages of SELM, which require students to work together in groups and have a responsibility in-group member so that they become peer tutoring. Ristanto et al. $(2018 \mathrm{a} ; 2018 \mathrm{~b})$ states that a cooperative strategy will develop students' relationships between groups, and they accept their classmates who are low academic achievers and increase students' selfesteem. Thus, it encourages the growth of peer tutor awareness among students. In line with the theory of Zone of proximal development (ZPD) by Vygotsky's (1978), Shabani, Khatib, Ebadi (2010) explained that individuals learn best when working together with others during collaboration, and it is through such collaborative endeavors with more skilled persons that students learn and internalize new concepts. Darmawan et al. (2018) also identifies the reason why using the constructive controversy approach in cooperative learning, which empowers students' metacognitive skills.

Hanham \& McCormick (2008) identified several studies showing that students can learn metacognitive skills better when working in cooperative groups. The reason is that the learning strategies centered has to do directly with the learning process. It includes an evaluation of the working group by group members, an assessment, and improvement of social interaction, as well as the efforts improving the appearance of each member of the group.

The questioning stage, the students were exposed to a search query by providing opportunities for students to ask. The step of mind mapping was an effort to train students' metacognitive skills. Fuad, et al (2017) stated that a question became one of the most common techniques to empower the higher-order thinking skills. Kirbulut (2015) said that the primary purpose of learning helps students to be able to regulate their learning process. Then learning that involves a series of questions such as SELM potentially improves the ability to regulate their learning process. Therefore, the achievement of student's metacognitive skills in the experimental class was significantly higher than the control class.

The question created by students will be checked and accessed in depth by the teacher with an assessment rubric to prevent students from cheating on each other. The question will be solved by exploring the primary source, that is the mindmap they have made and the book or open-source they make a reference in making a mindmap. It would be their responsibility at the writing stage. This stage aimed to empower the students' metacognitive skills by arranging related questions as a measurement of learning outcomes to develop the acquisition of metacognitive skills. The stage of exploring, the teacher acted as a facilitator. The teacher-guided students to search, analyze, interpret, and evaluate (Dunning, Johnson, Ehrlinger \& Kruger, 2003; Siswati, 2017; Rican, 2015; Runisah, 2017) asking students to read more learning resources to be able to answer questions or even be able to do practical activities in order to answer their questions. Then, exploring stage-trained students to ask themselves, so-called self-regulated learners. According to Lestari et al., (2019a), the role of the metacognitive skills in a 
student's learning is the students will be responsible for their learning progress and adapt modes of learning in achieving the task demands. Darmawan et al. (2018) also ensured that the involving activities in learning, such as the use of skills and the right model, are to solve problems and build metacognitive skills.

The communicating stage, in cooperative groups, students taught each other by upgrading their learning and teaching skills, understanding and experiencing their induction through the principle responding answers to questions that arise. Miyamoto, Pfost, and Artelt (2019); Caro (2019); Darmawan (2018); Buku (2016) have explained that metacognitive learning needs to pay attention to the interactions and relationships between students and teacher motivation. The stage of communicating represents cooperative learning that is indispensable in training metacognitive models. Because there are some aspects to activate metacognitive skills within the process of selfexamine and raise questions about the thoughts and self-correct (Zane, 2013; Kristiani 2015; Lestari 2019). Empowerment metacognitive skills in SELM syntax refers to Bannert et al., (2008) \& Hogan (2015). Metacognitive skills occur in the control activities, monitoring, self-regulation in learning, and problem-solving. Some studies show that self-regulation in learning has been used to improve academic achievement (Howse, Lange, Farran, \& Boyles, 2003; Perry, Hutchinson, \& Thauberger, 2007). Selfregulation in learning also makes students better in learning. Ristanto et al., (2018b) explains that the applied learning model is not only to convey the material but also to train students' thinking skills to use the full cognitive structure and focus. Therefore, the SELM in this study aims not only to convey the material but also to train the students' metacognitive skills.

\section{The Effect of Different Academic Level toward Student's Metacognitive Skills}

The results showed a significant relationship between the high and low levels of academics towards students' metacognitive skills. Phan (2012) stated that the higherlevel academics of students are several students who have the initial state is higher than the average level. While the lower level academic students are several students who have the initial state is lower than or equal to the average level. Furthermore, the high academic students have the initial state is better than the initial low academic students. This situation leads to a condition that high academic students have more confidence than low academic students. The fact was in line with test results stating that the low academic level students' metacognitive skills increased by $87.2 \%$ while the high academic students at $194.5 \%$. Students with high academic level after being taught with SELM have the ability to do self-evaluation and evaluate their learning activities so that their metacognitive abilities increase very well.

According to Darmawan et al. (2018), the development of metacognition-based learning strategies should provide experiences for students to pay attention to what is needed. Moreover, Lord (2001) suggested that peer teaching among students will increase their understanding of concepts and also their learning achievement. It is reasonable because, for the students of lower academic level, they need more time to learn with the assistance of another member group whose higher academic level during the learning process. 
Dunning et al. (2003) state that students with a high academic level must have high metacognitive skills and vice versa. The result in this study is consistent with research by Kristiani, et al. (2015) and Siswati, et al. (2017) that shows students with high academic level have higher academic success than lower academic level students. Similarly, the research of Isaacson \& Fujita (2006), which states that students of the high academic level could have higher metacognition skills than lower academic level students. Then, research of Berkowitz (2005) points out, the use of metacognitive reading strategies on students' high academic level and the students' low academic level shows different results.

The results of this study appear in line with what has been investigated by Ainley, Pratt, Hansen (2006), and Camahalan (2000), that there is a significant relationship between academic achievement with the use of self-regulated models. Zane (2013) explains that the self-regulated, which is a part of the highest levels of critical thinking skills equate with metacognitive. Kosnin (2007) reported that there was a significant relationship between self-regulated learning with academic achievement. The SELM which is learning model that develops self-regulated at every stage of its syntax will be able to create a learning ecology that makes students with various academic levels develop their metacognitive abilities

Cognitive activities such as planning to complete the task, understanding independently, monitoring, and evaluating progress can actively control the student's cognitive processes. Buku et al. (2016) showed that effective exercise by using metacognitive models to improve students' metacognitive control and enhance students' understanding. Metacognitive is a vital thing in learning and a strong predictor of academic success (Dunning et al., 2003). In addition, improving students' metacognitive can increase their learning outcomes (Baran \& Maskan, 2011; Lestari, Ristanto, \& Miarsyah, 2019a; Dent \& Koenka, 2016). Students with excellent metacognitive skills show better academic achievement than low metacognitive students (Kristiani et al., 2015; Lestari, Ristanto, \& Miarsyah, 2019b). Empowerment metacognitive skills performed on the SELM can encourage students to be independent learners who will have an impact on improving their learning outcomes. Metacognitive skills are one aspect of the knowledge dimensions that is necessary to understand things that are done (Rivers, 2001; Lestari. et al., 2019b).

The Effect of SELM Interaction with the Different Academic Level to Students Metacognitive Skills

SELM is able to make students with low academic levels have the same metacognitive skills level as students of high academic levels. Students with lower academic levels taught by SELM have similar results metacognitive skills with those whose higher academic level class taught by conventional teaching. The results of this study can be explained that the SELM can empower students' metacognitive skills. Several reasons can be described as follows. 1. The SELM can encourage students to enhance metacognitive skills. Through SELM, students will ask questions, solve problems, and collaborate with their groups (Darmawan, 2015). Some of the students' academic level improve continuously by SELM. 2. The SELM facilitates the development of analytical 
skills problem, arguing, developing ideas, providing solutions, criticizing, making decisions, and drawing conclusions based on careful consideration (Darmawan, 2016).

SELM ascertainable can empower students by using metacognitive skills. Metacognitive skills can not appear suddenly, but they must be trained with appropriate learning strategies. Independent learners can be taught and empowered through policies or specific measures (Siswati et al., 2017). It is further mentioned that if learners have metacognitive skills, they can become independent learners. The SELM encourages students to be active and independent in learning, and later they discuss the material they have learned in the other group members. Buku et al. (2016) state that the empowerment of metacognitive emphasis on self-monitoring and the responsibility of the student, according to Zane (2013) self monitoring is part of self regulation which is the highest level of thinking after ability to interpret, analyze, evaluate, make inferences, and communicate. The element of responsibility and communication to exchange information in the syntax of this learning model indicate that the model can empower students' metacognitive skills.

The syntax of SELM proved that students could learn better metacognitive skills when they worked in a cooperative group. Collaborative learning can facilitate students to acquire higher learning achievement (Baloche \& Brody, 2017; Loes \& Pascarella, 2017; Martini, Rosdiana, Subekti, \& Setiawan, 2018). Students are exposed to the conditions of the competitive environment in the cooperative learning which can strengthen the contribution of each student in achieving the group in giving a positive effect on student learning (Dyson \& Grineski, 2001). Students in the team were accommodating members of the academic performance with a variety of cooperative procedures Ristanto et al., (2018a). The formed group contained positive interdependence among fellow members of the group in mastering the problems and solutions to the issues that were being discussed within the group. The stage in the syntax of cooperative SELM supports individual responsibility and cooperation among groups. Some of the results showed that self-regulated learning could be used to improve learning outcomes (Howse, Lange, Farron \& Boyles, 2003); Perry, Hutchsinson, \& Thauberger, 2007). The responsibility of students is part of self-regulated learning. By increasing the sense of responsibility through SELM, the students will be able to improve their metacognitive skills.

\section{CONCLUSION}

Simas Eric Learning Model (SELM) can improve students' metacognitive skills. The SELM can facilitate students with low academic metacognitive skills to equalize the high academic students taught by conventional learning models. There is no significant difference between low academic level students taught by SELM and high academic level students taught by conventional teaching models. Students with high academic level taught by SELM have metacognitive skills higher than a conventional classroom.

\section{Limitation and Implication}

This research it is still limited in terms of participants, namely only from biology subjects. This limitation may reflect one of the barriers to generalize the results of this study to become a broader scope of education. However, several implications can be taken in this study. First, SELM can be an alternative learning model that potentially 
increases students' metacognitive skills for students in secondary schools, especially in Indonesia. The learning model that is born from the thought of constructivism, which is believed to be able to prepare students in the demands of global competition. Being independent and resilient learner are the key to success in all activities both at school and outside of school. Secondly, as educators, teachers should pay attention to students who have a low academic level. These particular students should receive more attention from the teacher in the classroom learning process. Proper before learning becomes the key to success in achieving the goals of learning. It indicates that a teacher has the primary role and forefront of education in the classroom (Wahono \& Chang, 2019). Finally, this research can be a pattern for conducting other similar research studies that emphasize special attention to low-ability students without ignoring other students. Every student has the same chance to get a better education. Likewise, it is also the basis for researchers who are interested in trying to implement SELM to solve any problem faced in a classroom.

\section{REFERENCES}

Ainley, J., Pratt, D., \& Hansen, A. (2006). Connecting engagement and focus in pedagogic task design. British Educational Research Journal, 32(1), 23-38.

Alexander, P. A., \& Jetton, T .L. (2000). Learning from text: A multidimensional and developmental perspective. In M. L. Kamil, P. B. Mosenthal, P. D. Pearson, \& R. Barr (Eds.), Handbook of reading research, vol. 3 (pp.285-310). Lawrence Erlbaum.

Almala, A. H. (2005). A constructivist conceptual framework for quality-learning environment. Distance Learning, 2(5), 9-12.

Alves, A. F., Gomes, C. M. A., Martins, A., \& Almeida, L. D. S. (2017). Cognitive performance and academic achievement: How do family and school converge? European Journal of Education and Psychology, 10, 49-56.

Amin, I., \& Sukestiyarso, Y. L. (2015). Analysis metacognitive skills on learning mathematics in high school. Int. Journal of Education and Research, 3(3), 213-222.

Asy'ari, M., \& Ikhsan, M. (2019). The effectiveness of inquiry learning model in improving prospective teachers' metacognition knowledge and metacognition awareness. International Journal of Instruction, 12(2), 455-470.

Baloche, L., \& Brody, C. M. (2017). Cooperative learning: exploring challenges, crafting innovations. Journal of Education for Teaching, 43(3), 274-283. https://doi.org/10.1080/02607476.2017.1319513.

Bannert, M., \& Mengelkamp, C. (2008). Assessment of metacognitive skills by means of instruction to think aloud and reflect when prompted. Does the verbalization method affect learning? Metacognition and Learning, 3(1), 39-58.

Baran, M., \& Maskan, A. K. (2011). Investigation multiple intelligence fields of 11thgrade students with respect to some variables and physics achievement. Necatibey Faculty of Education E-J. of Science and Mathematics Education, 5(2), 146-177.

Berkowitz, E. (2005). Metacognitive reading strategies of gifted high achieving and gifted underachieving urban adolescent students. Paper presented at the American Educational Research Association Conference, Montreal, Canada. 
Borovay, L. A., Shore, B. M., Caccese, C., Yang, E., \& Hua, O. (2019). Flow, achievement level, and inquiry-based learning. J. of Advanced Acad., 30(1), 74-106.

Buku, M. N. I., Corebima A. D, \& Fatchur, R. (2016). The correlation between metacognitive skills and the critical thinking skills of the senior high school students in biology learning through the implementation of problem-based learning (pbl) in Malang, Indonesia. Int. Journal of Academic Research and Development, 1(5), 58-63.

Camahalan, F. M. G. (2000). Effect of self-regulated learning on mathematics achievement of selected Southeast Asian children. J. of Ins. Psyc., 33(3), 194-205.

Caro, M. F., Josyula, D. P., Madera, D. P., Kennedy, C. M., \& Gomez, A. A. (2019). The Carina metacognitive architecture. International Journal of Cognitive Informatics and Natural Intelligence, 13(4), 71-90. doi.10.4018/IJCINI.2019100104.

Choi, I., Land, S. M., \& Turgeon, A. (2005). Scaffolding peer-questioning strategies to facilitate metacognition during small group discussion. Inst. Science, 33(5), 483-511.

Cubukcu, F. (2008). Enhancing vocabulary development and reading comprehension through metacognitive strategies. Issues In Educational Research, 23(2), 132-150.

Darmawan, E. (2012). The effect of integration of the simulation learning model with blended learning on student learning outcomes (The influence of the integration of the simulation learning model with blended learning on student learning outcomes). Jurnal Penelitian Kependidikan, 2(2), 17-32.

Darmawan, E., Alamsyah, M. R. N., Permadani, K. G., Pamungkas, S. J., Prajoko, S., Sukmawati, I., Wahono, B., \& Zamzami, M. R. A. (2019). Integration of Simas eric with google classroom: enhancing biology students motivation and scientific writing. Biosfer: Jurnal Pendidikan Biologi, 12(1), 1-12. doi:10.21009/biosferjpb.v12n1.1-12.

Darmawan, E., Brasilita, Y., Zubaidah, S., \& Saptasari, M. (2018). Enhancing metacognitive skills of students with different gender using Simas eric learning model at state senior high school 6 Malang. Biosfer: Jurnal Pendidikan Biologi, 11(1), 48-57.

Darmawan, E., Zubaidah, S., Susilo, H., \& Suwono, H. (2016). Simas eric model to improve students' critical thinking skills. J. of Education \& Social Policy, 3(6), 45-53.

Darmawan, E., Zubaidah, S., Susilo, H., \& Suwono, H. (2015). Developing an instructional model using a learning development cycle: a sample of Simas eric model to improve students'critical thinking skills. SMTE, 129.

Dent, A. L., \& Koenka, A. C. (2016). The relation between self-regulated learning and academic achievement across childhood and adolescence: a meta-analysis. Educational Psychology Review, 28(3), 4250474. doi:10.1007/s10648-015-9320-8.

Dunning, D., Johnson, K., Ehrlinger, J., \& Kruger, J. (2003). Why people fail to recognize their own incompetence. Current Directions in Psyc. Sci., 12(3), 83-87.

Dyson, B., \& Grineski, S. (2001). Using cooperative learning structure in physical education. Journal of Physical Education, Recreation, and Dance, 72(2), 28-31.

Fauzi, A., \& Fariantika, A. (2018). Courses perceived difficult by undergraduate students majoring in biology. Biosfer: Jurnal Pendidikan Biologi, 11(2), 78-89. doi:10.21009/biosferjpb.v11n2.78-89. 
Flavell, J. H. (1992). Perspectives on perspective taking, Piaget's theory: Prospects and possibilities. Hillsdale: Erlbaum.

Fuad, N. M., Zubaidah, S., Mahanal, S., \& Suarsini, E. (2017). Improving junior high schools' critical thinking skills based on test three different models of learning. International Journal of Instruction, 10(1), 102-116.

Gagne, F. (1995). From giftedness to talent: a developmental model and its impact on the language of the field. Roeper Review, 18(2), 103-111.

Handoko, F., Nursanti, E., Harmanto, D., \& Sutriono. (2016). The role of tacit and codified knowledge within technology transfer program on technology adaptation. ARPN Journal of Engineering and Applied Sciences, 11(8), 5275-5282.

Hanham, J.,\& McCormick, J. (2008). Relationships between self-processes and group processes with friends and acquaintances. Issues in Edu. Research, 23(2), 132-150.

Hariyadi, S., \& Corebima, A. D. (2019). The distribution of patterns and types of questions in genetic learning implementing reading-questioning-answering learning model. International Journal of Environmental and Science Education, 14(8), 469-477.

Herlina, M., Azhar, A., \& Irianti, M. (2018). Application of Simas eric Model to Improve Student Cognitive Learning Outcomes in Global Warming Materials in Class XI of MAN 1 Pekanbaru. J. On. Mahasiswa Bidang Keg. dan Il. Pendi., 5(1), 164-171.

Howse, R. B., Lange, G., Farran, D. C., \& Boyles, C. D. (2003). Motivation and selfregulation as predictors of achievement in economically disadvantaged young children. The Journal of Experimental Education, 77(2), 151-174.

Isaacson, R. M., \& Fujita, F. (2006). Metacognitive knowledge monitoring and selfregulated learning: academic success and reflections on learning. Journal of the Scholarship of Teaching and Learning, 6(1), 39-55.

Jones, B.D., Ruff, C., Syder, J.D., Petrich, B., \& Koonce, C. (2012). The effects of mind mapping activities on students' motivation. International Journal for the Scholarship of Teaching and Learning, 6(1), 1-21.

Hogan, M. J., Dwyer, C. P., Harney, O. M., Noone, C., \& Conway, R. J. (2015). Metacognitive skill development and applied systems science: A framework of metacognitive skills, self-regulatory functions and real-world applications. In A. PenaAyala (Ed.), Metacognition: Fundaments, applications, and trends (pp. 75-106). Springer, Cham.

Kirbulut, Z. D. (2015). Modeling the relationship between high school students' chemistry self-efficacy and metacognitive awareness. International Journal of Environmental \& Science Education, 9, 177-196.

Kosnin, A.M. (2007). Self-regulated learning and academic achievement in Malaysian undergraduates. International Education Journal, 8(1), 221-228.

Kristiani, N., Susilo, H., Rohman, F., \& Corebima. (2015). The contribution of students' metacognitive skills and scientific attitude towards their academic achievements in biology learning implementing Thinking empowerment by questioning (TEQ) learning 
integrated with inquiry learning (TEQI). International Journal of Educational Policy Research and Review, 2(9), 113-120.

Lam, K. K. L., \& Zhou, M. (2019). Examining the relationship between grit and academic achievement within K-12 and higher education: A systematic review. Psychology in the Schools, 56(10), 1654-1686.

Lauca, E. P. (2003). The concept and instruction of metacognition. Teacher Development, 7(1), 9-30.

Lestari, P., Ristanto, R.,H., \& Miarsyah, M. (2019a). Analysis of conceptual understanding of botany and metacognitive skill in pre-service biology teacher in jakarta, indonesia. Journal for the Education of Gifted Young Scientists, 7(2), 199-214.

Lestari, P., Ristanto, R. H \& M. Miarsyah. (2019b). Metacognitive and conceptual understanding of pteridophytes: development and validity testing of an integrated assessment tool. Indonesian Journal of Biology Education, 2(1), 15-24.

Liu, Y., Zhao, G., Ma, G., \& Bo, Y. (2014). The effect of mind mapping on teaching and learning: A meta-analysis. Standard Journal of Education and Essay, 2(1), 17-31.

Loes, C. N., \& Pascarella, E. T. (2017). Collaborative Learning and Critical Thinking: Testing the Link. The Journal of Higher Education, 88(5), 726-753. doi:10.1080/00221546.2017.1291257.

Lord, T. R. (2001). 101 Reasons for using cooperative learning in Biology teaching. The American Biology Teacher, 63(1), 30-337.

Lukitasari, M., Susilo, H., Ibrohim, I., \& Corebima, A. D. (2014). Lesson study in improving the role of e-portfolio on the metacognitive skill and concept comprehension: a study on cell biology subject in IKIP PGRI Madiun, Indonesia. American Journal of Educational Research, 2(10), 919-924.

Martin, B. L., Joel, J., Mintzes, \& Ileana, E. C. (2010). Restructuring knowledge in Biology: cognitive processes and metacognitive reflections. International Journal of Science Education, 22(3), 303-323.

Martini, Rosdiana, L., Subekti, H., \& Setiawan, B. (2018). Strengthening students' characters and ecopreneurship through science, environment, technology, and society course. Jurnal Pendidikan IPA Indonesia, 7(2), 162-171. doi:10.15294/jpii.v7i2.14338.

Moore, D. M., \& Dwyer, F. M. (2001). The relationship of field dependence and colorcoding to female students' achievement. Journal Perceptual and Motor Skill, 93, 81-85.

Miharja, F. J., Hindun, I., \& Fauzi, A. (2019). Critical thinking, metacognitive skills, and cognitive learning outcomes: a correlation study in genetic studies. Biosfer: Jurnal Pendidikan Biologi, 12(2), 135-143. doi:10.21009/biosferjpb.v12n2.135-143.

Miyamoto, A., Pfost, M., \& Artelt, C. (2019). The relationship between intrinsic motivation and reading comprehension: Mediating effects of reading amount and metacognitive knowledge of strategy use. Scientific Studies of Reading, 23(6), 445-460.

Nielsen, B. M. (2019). Fostering learner autonomy in foreign language learning: justifications, definitions, misconceptions, and interrelated components for its realization. HOKUGA, 8(1), 33-52. 
O’Connor, M., Cloney, D., Kvalsvig, A., \& Goldfeld, S. (2019). Positive mental health and academic achievement in elementary school: new evidence from a matching analysis. Educational Researcher, 48(4), 205-216.

Permana, F., \& Chamisijatin, L. (2019). Project-based learning through edmodo: improving critical thinking and histology concepts. Biosfer: J. Pend. Biologi, 12(1).

Perry, N. E., Hutchinson, L., \& Thauberger, C. (2007). Mentoring student teachers to design and implement literacy tasks that support self-regulated learning and writing. Reading and Writing Quarterly, 23, 27-50.

Phan, H. P. (2012). Prior academic achievement, effort, and achievement goal orientations: A longitudinal examination. J. of Edu. and Develop. Psyc., 2(2), 57-71.

Pratama, A. (2018). Improving metacognitive skills using problem-based learning (pbl) at natural science of primary school in deli serdang, indonesia. Biosfer: Jurnal Pendidikan Biologi, 11(2), 101-107.

Putri, E. K., Irianti, M., \& Azhar, A. (2018). Application of Simas eric Model to Improve Student Cognitive Learning Outcomes in Global Warming Materials in Class XI of MAN 1 Pekanbaru. J. On. Mahasiswa Bidang Keg. dan Ilmu Pendi., 5(1), 47-55.

Rican, P. D. J. S. J. (2015). Metacognitive strategies: Asset to efficient learning and education. Slavonic Pedagogical Studies Journal, 5(1), 31-39.

Ristanto, R. H., Zubaidah, S., Amin, M., \& Rohman, F. (2018a). The potential of cooperative integrated reading and composition in biology learning at higher education. International Journal of Educational Research Review, 3(1), 50-56.

Ristanto, R. H., Zubaidah, S., Amin, M., \& Rohman, F. (2018b). From a reader to a scientist: developing cirgi learning to empower scientific literacy and mastery of biology concept. Biosfer: Jurnal Pendidikan Biologi, 11(2), 90-100.

Riswanto, \& Putra, P. P. (2012). The use of mind mapping strategy in the teaching of writing at SMAN 3 Bengkulu, Indonesia. Int. J. of Human. and Soc. Sci., 2(2), 60-68.

Rivers, W. (2001). Autonomy of all costs: An ethnography of metacognitive selfassessment and self-management among experienced language learners. Moderns Language Journal, 86(2), 279-290.

Runisah, R., Herman, T., \& Dahlan, J. A. (2017). Using the 5E learning cycle with metacognitive technique to enhance students' mathematical critical thinking skills. International Journal on Emerging Mathematics Education, 1(1), 87-98.

Schraw, G., Flowerday, T., \& Lehman, S. (2001). Increasing situational interest in the classroom. Educational Psychology Review, 13(3), 211-224.

Sele, Y. (2016). The analysis of the teaching habit effect based on conventional learning in empowering metacognitive skills and critical thinking skills of senior high school students in Malang, Indonesia. Int. J. of Academic Research and Development, 1, 64-69.

Shabani, K., Khatib, M., \& Ebadi, S. (2010). Vygotsky's zone of proximal development: instructional implications and teachers' professional development. English Language Teaching, 3(4), 237-248. 
Sheikh, I., Soomro, K. A., \& Hussain, N. (2019). Metacognitive awareness of reading strategies, reading practices and academic attainments of university students. Journal of Education and Educational Development, 6(1), 126-137.

Siemens, G. (2005). Learning Development Cycle: Bridging learning design and modern knowledge needs. Int. J. of Inst. Technology and Distance Learning, 2(1), 1-17.

Siswati, B. H., \& Corebima, A. D. (2017). The effect of education level and gender on students' metacognitive skills in Malang, Indonesia. Advances in Social Sciences Research Journal, 4(4) 163-168.

Sumiati, I. D., Mahanal, S., \& Sunarmi. (2016). The influence of Simas Eric's learning model on retention and learning outcomes of biology students of class XI in SMAN 1 Malang (Simas Eric Learning model influence on the retention and learning outcomes of biology class XI student at SMAN 1 Malang). Malang: Universitas Negeri Malang, Proceeding at National Seminar and Workshop on Basic Education.

Sungur, S., \& Yerdelen, S. (2011). Examination of the self-regulated learning processes for low and high achievers in biology. New Educational Review, 24(20), 207-215.

Supriyatin, Rahayu, S., Ristanto, R. H., \& Ichsan, I. Z. (2019). Improving hots in biology learning: A supplement book of plant growth and development. Universal Journal of Educational Research, 7(12), 2642-2646

Susantini, E., Indana, S., Isnawati, I., \& Nursanti, A. (2019). Enabling Indonesian preservice teachers to design biology learning tools using metacognitive strategy. Jurnal Pendidikan IPA Indonesia, 8(3), 391-397

Suskie, L. (2018). Assessing student learning: A common sense guide. San Fransisco: John Wiley \& Sons, Inc.

Vygotsky, L. S. (1978). Mind in society: The development of higher psychological processes. Cambridge, MA: Harvard University Press.

Wahono, B., \& Chang, C-Y. (2019). Assessing teacher's attitude, knowledge, and application (AKA) on STEM: An effort to foster the sustainable development of STEM education. Sustainability, 11, 950.

White, G. P., \& Greenwood, S. C. (2015). Empowering middle level students through the use of learning contracts. Middle School Journal, 23(5), 15-20.

Yusnaeni. (2018). Enhancing student's learning outcomes with different academic level using metacognitive strategies. J. of Phys.: Conf. S., 1028(1). Doi: 10.1088/1742$6596 / 1028 / 1 / 012029$.

Zane, T. (2013). Implementing critical thinking with signature assignments. Salt Lake: Salt Community College-USA.

Zohar, A., \& Barzilai, S. (2013). A review of research on metacognition in science education: Current and future directions. Studies in Science Education. 10(2), 1-47. 